\title{
A study on the existence of Vibrio cholerae non-O1 in the river
}

\author{
Hidekazu Uchiyama
}

Received: 7 August 2014/ Accepted: 24 November 2014/Published online: 14 December 2014

(C) The Japanese Society for Hygiene 2014

\begin{abstract}
Objective The aim of the present study is Vibrio cholerae non-O1 existing in river. Bacteria are known to inhabit all kinds of environment. Vibrionaceae is widely distributed in environmental water. Vibrio spp. have been identified as a cause of toxicity in fish and shellfish. One condition affecting the survival of pathogenic microorganisms in environmental water is the salt concentration, and they have been reported to inhabit brackish water. However, $V$. cholerae non-O1 has also been detected in fresh water, and its properties suggest that it can survive in river water.

Methods Sampling was performed 4 times at 4 points during a 5-month period from July to November at about 1-month intervals from the Sagami River in 1985. River water bacteria were identified, and $V$. cholera non-O1 isolated. I investigated the relationship between the bacterial flora in river water and the detection of $V$. cholerae non-O1.

Results There were significant differences in the composition of bacterial flora with and without the isolation of $V$. cholerae non-O1 (Chi-square test) $\left(\chi^{2}=24.70>22.0\right.$ $(p=0.005), \mathrm{df}=8)$. A correlation between changes in the composition of the river water bacterial flora and detection of $V$. cholerae non-O1 was identified.

Conclusion Therefore, V. cholerae non-O1 exists in the river.
\end{abstract}

\footnotetext{
H. Uchiyama ( $\square)$

Laboratory of Public Health, Department of Health Dietetics, Faculty of Health Promotional Sciences, Hamamatsu University, 1230 miyakodacho Kita-ku, Hamamatsu-Shi,

Shizuoka-ken 431-2102, Japan

e-mail: uchi@hm.tokoha-u.ac.jp
}

Keywords Vibrio cholerae - River water · Flora . Ecology $\cdot$ Environmental microbacteria

\section{Introduction}

Bacteria inhabiting rivers have been studied in conjunction with evaluation of the water quality [1], identification of cleaning bacteria for the exploitation of water sources, etc. [2], and changes in the resident flora associated with alterations in the quality of river water [3, 4]. Bacteria of the family Vibrionaceae are widely distributed in sea and fresh water environments. Their ecology in bays and oceans has been investigated in detail, and their frequent and extensive presence in environmental water has been established [5]. The survival of pathogenic halophilic bacteria that may cause diseases in humans has been discussed extensively, and a consensus on the environmental conditions they require appears to have been reached [6]. However, Vibrio cholerae non-O1 produces cholera-like enterotoxin [7] and the infection of $V$. cholerae non-O1 was caused by polluted food [8]. It is thus necessary to establish a possibility that $V$. cholerae non-O1 can exist in river for preventing infection. $V$. cholerae non-O1 has been isolated from river where salinity concentration was $2 \%$ or lower, suggesting the possibility of it inhabiting and proliferating in rivers [9]. And a relationship between the isolation of $V$. cholerae non$\mathrm{O} 1$ and number of viable bacteria has been reported [10]. It has been reported that $V$. cholerae non-O1 is frequently isolated after outbreaks of $V$. cholerae $\mathrm{O} 1$ [11]. There is also an included risk of infection and danger of existence of $V$. cholerae $\mathrm{O} 1$ which is merely different in serotype from $V$. cholerae non-O1. In this study, I report the concurrence of changes in the resident bacterial flora in river water and detection of $V$. cholerae non-O1. 


\section{Materials and methods}

Sampling points

Figure 1 shows the sampling points along the Sagami River, which flows through central Kanagawa Prefecture. Water of the Sagami River is sluiced from the Tsukui Dam near Point 1. Point 2 is located slightly upstream of a water gate with an intake from a water treatment plant. Point 3 is located where the width of the river widens, and fishing boats come and go. The highly contaminated Hato River flows into the Sagami River upstream of this point. There is a dam immediately upstream of Point 4, but sea water may flow back to this point at full tide. The salinity of the Sagami River was $2 \%$ or lower. The salinity increased, when going downstream [10].

\section{Methods of river water sampling}

In 1985, water quality and isolation of $V$. cholerae non-O1 was investigated in the Sagami River [10]. At the same time, river bacteria were isolated and stored. In this report, the changes in the resident flora are studied by the statistical method. Sampling was performed 4 times at each point during a 5-month period from July to November at about 1-month intervals.

Method for the isolation of viable bacteria from river water

The sampled water was transported to the laboratory within $4 \mathrm{~h}$ and analyzed [12]. The sample was serially diluted with
$0.85 \% \mathrm{NaCl}$ solution, smeared over nutrient agar (Eiken Chemical Co., Ltd.), cultured at $37{ }^{\circ} \mathrm{C}$ for $24 \mathrm{~h}$, and the colonies were counted. Also, 20-30 colonies on the medium were randomly selected, cultured for purification, and stored in heart infusion agar (Difco) as isolates from river water.

Identification of river water bacteria

The stored bacterial strains isolated from river water were cultured in nutrient agar at $37{ }^{\circ} \mathrm{C}$ for $24 \mathrm{~h}$, and were identified by performing the tests [2] according to a guide [13].

Method for the isolation of Vibrio cholerae non-O1

Immediately after sampling, $450 \mathrm{ml}$ of river water was mixed with $50 \mathrm{ml}$ of alkaline peptone water prepared at 10 times the typical concentration, cultured for $6 \mathrm{~h}$, and secondary enrichment culture was performed using salt-free alkaline peptone water, followed by isolation culture using Thiosulfate Citrate Bile Salts Sucrose agar medium (TCBS agar medium; Eiken Chemical Co., Ltd.). The bacteria forming colonies on the TCBS agar medium were identified using the tests [14]. V. cholerae non-O1 was not agglutinated by $V$. cholerae $\mathrm{O} 1$ to anti-O1 serum test.

\section{Statistical observation}

Relation between the river bacterial flora and the isolation of $V$. cholerae non-O1 tested Chi-square test $\left(\chi^{2}\right.$, $p=0.005)$.
Fig. 1 Sagami river sampling points locations: 1 Ogura-hashi, 2 Shouwa-hashi, 3 Sagamiohohashi, 4 Kamikawa-hashi

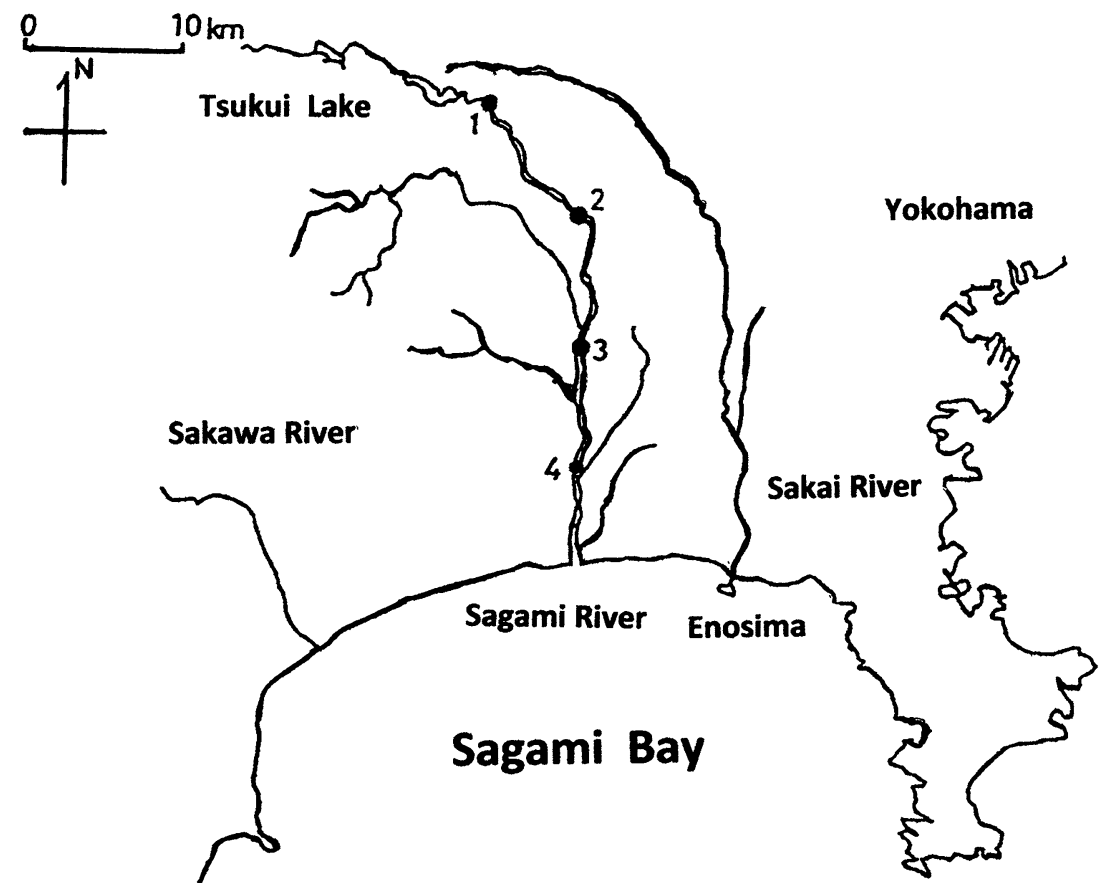




\section{Results}

Table 1 shows the number and rate of river water bacteria from Sagami River. Four genera of Flavobacterium (20.6\%), Moraxella (21.0\%), Aeromonas (17.6\%) and Pseudomonas (13.6\%), were isolated at high rates for a period of investigation. Other bacterial genera accounted for about $1 \%$ and were not always isolated. So, no characteristic was related to season and the sampling point.

Monthly data on river water bacterial flora

On the change of the seasons, the percentage of Flavobacterium and Moraxella changed from over $30 \%$ and to less than $20 \%$, showing a tendency to decrease toward winter. The rate of Pseudomonas and Aeromonas was about $5 \%$ throughout most of the observation period, except for Aeromonas in October (38.3\%) and Pseudomonas in November $(33.3 \%)$.

River water bacterial flora at various sampling points

On the points when going downstream, the rate of Flavobacterium and Moraxella was increased, while the rate of Aeromonas, Enterobacteriaceae and Pseudomonas showed a tendency to decrease.

Relationship between the isolation of $V$. cholerae non$\mathrm{O} 1$ and bacterial flora

The rate of Moraxella was about $10 \%$ more than without the isolation of $V$. cholerae non-O1. However, the rate of Aeromonas was showing a $10 \%$ difference in the opposite direction. The rate of Flavobacterium was 22.8 and $19.9 \%$, and that of Pseudomonas was 13.7 and $13.5 \%$, with and without the isolation of $V$. cholerae non-O1, respectively, showing no marked difference. At Point 1, $V$. cholerae non-O1 was not isolated. There were significant differences in the composition of bacterial flora with and without the isolation of $V$. cholerae non-O1 (Chisquare test $)\left(\chi^{2}=24.70>22.0(p=0.005), \mathrm{df}=8\right)$.

\section{Discussion}

Vibrio cholerae $\mathrm{O} 1$ invited sometimes pandemic infection in the world, or invaded our country through travelers from infected areas. The cholera patients contaminated river water by $V$. cholerae $\mathrm{O} 1$. The isolation of $V$. cholerae $\mathrm{O} 1$ is superior to that of $V$. cholerae non-O1 immediately after a cholera epidemic. V. cholerae adapted in aquatic environment, and only $V$. cholerae non-O1 isolated in process of time $[11,15,16]$. V. cholerae cannot exist under low 
temperature and it is known that it cannot exist through winter in Japan. Therefore, the isolation of $V$. cholerae non-O1 from aquatic environment has been considered for the river pollution from that cholera patients, and it is not thought $V$. cholerae non-O1 exists in the river. However, it was reported that $V$. cholerae appear to exist as an autochthonous member of the bacterial flora [17]. However, it has been reported that $V$. cholerae inhabit various aquatic environments, and $V$. cholerae non-O1 is more adaptable than $V$. cholerae $\mathrm{O} 1$ in the environment [18]. The environmental conditions enable $V$. cholerae non-O1 to exist in the low temperature river [19]. The Sagami River was once contaminated by $V$. cholerae $\mathrm{O} 1$ [20], and $V$. cholerae non-O1 may have inhabited the Sagami River after this. It has been considered that $V$. cholerae inhabited the river.

Bacteria of the genus Vibrio inhabit sea water in river mouths and bays [17]. The author evaluated the possibility of $V$. cholerae non-O1 inhabiting river water. Toxin-producing $V$. cholerae non-O1 has been isolated from environmental water such as Chesapeake Bay [7] and Colorado River [21]. Since various toxins have been reported from toxin-producing bacteria [22], the screening of bacteria using other toxin-detecting methods is necessary, and the possibility of infection by unknown toxin-producing bacteria must be considered.

The increase of coliform or Escherichia coli is designated that water was polluted by any matter involving feces. These are used an index of the proportion of environmental pollution. The number of $E$. coli was not correlated to whether or not $V$. cholerae non-O1 was isolated from river water, and the speculation that river water is contaminated by feces of humans or animals infected by $V$. cholerae non-O1 have been refuted [23]. Our investigation along the Sagami River showed no correlation between the isolation of $V$. cholerae non-O1 and number of coliform [10]. It is suggested that the isolation of $V$. cholerae non-O1 was not polluted by feces. And the $V$. cholerae non-O1 inhabits rivers.

There is a report that the incidence of $V$. cholerae non$\mathrm{O} 1$ infection increases with the amount and frequency of isolation of $V$. cholerae non-O1 [8]. The presence of $V$. cholerae non-O1 suggests that it may proliferate depending on the environmental conditions and increases the risk of infection in humans through contaminated water or sea foods [24]. Reports concerning infection from sea foods have stressed the relationship between the water quality or isolation of bacteria and the salt concentration [25, 26]. Some nutrients are necessary for the growth of bacteria [9]. Concerning the presence of $V$. cholerae non-O1 in freshwater, it was isolated at salt concentrations of 4-17\% in an investigation of the Chesapeake Bay [7] and at $\mathrm{Na}^{+}$ concentrations of $5 \mathrm{mM}$ or less in Colorado River water, suggesting the possibility of its inhabitation [21]. In our investigation of the Sagami River, $V$. cholerae non-O1 isolated at $\mathrm{Na}^{+}$concentration of $1 \mathrm{mM}$ or less, salinity concentration was $2 \%$ or lower, $V$. cholerae non-O1 is considered to survive at this salt concentration [10].

According to the results of analysis of the bacterial flora, Flavobacterium, Moraxella, Pseudomonas, and Aeromonas were major isolates in this river, indicating that they are resident bacteria of rivers, as reported by Maeda [17]. In this study, their rates in the bacterial flora of river water were examined. By season, the rates of Flavobacterium and Moraxella decreased from summer to winter. In this investigation water temperature was $13.4-26.0{ }^{\circ} \mathrm{C}$ [10]. By sampling site, the rates of Flavobacterium and Moraxella increased, but those of Pseudomonas and Aeromonas decreased, from upstream to downstream. The rates of Flavobacterium and Moraxella were high in summer, when $V$. cholerae non-O1 was detected, and low in winter, similar to the difference between up- and downstream associated with the difference in the salt concentration. At Point 1, water temperature is always lower than it at the other point, but salinity is not always lower than it at the other point. $V$. cholerae non-O1 is not so propagated that it is isolated from Point 1 for low water temperature. The composition of river water bacterial flora was significantly correlated with the detection of $V$. cholerae non-O1. The detection of $V$. cholerae non-O1 and changes in the composition of river water bacterial flora suggest the possibility of survival of $V$. cholerae non-O1 in rivers. Interactions among river bacteria, which are affected by differences in the water quality at various sampling points may be related to the survival of $V$. cholerae non-O1, and $V$. cholerae nonO1 may inhabit rivers in areas in which bacteria of the genus Vibrio are detected [27]. This suggests that $V$. cholerae does not only inhabit estuaries but also river waters. In addition, we regard that $V$. cholerae was increased by the environmental change and was susceptible to $V$. cholerae.

In conclusion, $V$. cholerae non-O1 has been isolated from fresh river water and is thought to inhabit as a river bacteria flora.

Conflicts of interest The author declare that no conflict of interest.

\section{References}

1. Tanaka N, Ueda Y, Onizawa M, Kadota H. Bacterial populations in water masses of different organic matter concentrations in Lake Biwa. Jap J Limnol 1977;38:41-7. (Article in Japanese).

2. Maeda S. The flora of aerobic heterotrophic bacteria in the River Sagami. Jap J Limnol. 1980;41:163-71 (Article in Japanese).

3. Morikawa K. Seasonal fluctuation in the number of bacteria and its relation to environmental factors in the upper region of the Tamagawa River. Jap J Limnol. 1984;45:69-78 (Article in Japanese). 
4. Lin S, Evans LR, Beuscher BD. Bacteriological assessment of Spoon River water quality. Appl Microbiol. 1974;28:288-97.

5. Simidu U, Kogure K, Tsukamoto K. Distribution of Vibrionaceae in the Sea. Nihon Biseibutu Seitai Gakkaiho. 1987;1:65-74.

6. Miwatani T, Takeda Y. Vibrio parahaemolyticus - a causative bacterium of food poisoning. Saikon: Tokyo; 1976.

7. Kaper J, Lockman H, Colwell RR, Joseph SW. Ecology, serology and enterotoxin production of Vibrio cholerae in Chesapeake Bay. Appl Environ Microbiol. 1979;37:91-103.

8. Williams LA, LaRock PA. Temporal Occurence of Vibrio species and Aeromonas hydrophila in estuarine sediments. Appl Environ Microbiol. 1985;50:1490-5.

9. Uchiyama H. Survival of Vibrio cholerae non-O1 in freshwater river. Jpn J Public Health. 1997;44:547-57 (Article in Japanese).

10. Uchiyama H, Todoroki T. Water quality and isolation of Vibrio cholerae non-O1 from an aquatic environment. J J A Inf D. 1989;63:1313-21.

11. Kenyon JE, Gillies DC, Piexoto DR, Austin B. Vibrio cholerae (non-O1) isolated from California coastal waters. Apple Environ Microbiol. 1983;46:1232-3.

12. American Public Health Association. Standard methods for the examination of water and wastewater 15 th ed. Washington DC;1980. p. 789.

13. Cowan ST, Steel KJ. Manual for identification of medical bacteria. Cambridge of the university press 1965. Sakazaki T. (Version) Kindai-press;1974. (Article in Japanese).

14. Educational committee of Japanese society for bacteriology. Examination method for Vibrio cholerae and enterotoxigenic Escherichia coli. Tokyo, Saikon; 1981. p. 9-19. (Article in Japanese).

15. Nair GB, Oku Y, Takeda Y, Ghosh A, Ghosh RK, Chattopadhyay $\mathrm{S}$, et al. Toxin profiles of Vibrio cholerae non-O1 from environmental Sources in Calcutta, India. Appl Environ Microbiol. 1988;54:3180-2.

16. Takita S, Watanabe K, Maruyama K, Emoto K, Hirayama H, Kodaka C, et al. Pathogenic and survive of Vibrio cholera isolated from Mama-River in Itikawa-shi at 1979. Jpn J Public Health. 1980;27:535-42 (Article in Japanese).

17. Colwell RR, Kaper J, Joseph SW. Vibrio cholerae, Vibrio parahaemolyticus and other vibrio. Science. 1977;198:394-6.

18. Colwell RR, editor. Vibrios in the environment. New York: Wiley; 1984.

19. Uchiyama H. Survival of Vibrio cholerae non-O1 in river sediment during cold season. J J A Inf D. 1998;72:218-22 (Article in Japanese).

20. Fukumi H. Cholerae. Sci Karada. 1980;92:20-5 (Article in Japanese).

21. Rhodes JB, Smith HL, Ogg JE. Isolation of non-O1 Vibrio cholerae serovers from surface waters in Western Colorado. Appl Environ Microbiol. 1986;51:1216-9.

22. Craig JP, Yamamoto K, Takeda T, Miwatani T. Production of cholera-1ike enterotoxin by a Vibrio cholerae non-O1 strain isolated from the environment. Infect Immun. 1981;34:90-7.

23. Hood MA, Ness GE. Survival of Vibrio cholerae and Escherichia coli in estuarine waters and sediments. Appl Environ Microbiol. 1982;43:578-84.

24. Wilson R, Lieb S, Roberts A, Stryker S, Janowski H, Gunn R, et al. Non-O group 1 Vibrio cholerae gastroenteritis associated with eating row oysters. Am J Epideniol. 1981;114:293-8.

25. Garay E, Arnau A, Amaro C. Incidence of Vibrio cholerae and related Vibrio in a coastal lagoon and seawater influenced by lake discharges along an annual cycle. Appl Environ Microbiol. 1985;50:426-30.

26. Lin F-YC, Morris JGJR, Kaper JB, Gross T, Michalski J, Morrison C, et al. Persistence of Cholera in United States: isolation of Vibrio cholerae $\mathrm{Ol}$ from a patient with diarrhea in Maryland. J Clinic Microbiol. 1986;46:1232-3.

27. Uchiyama H. Distribution of Vibrio species isolated from aquatic environments with TCBS agar. Environ Health Prev Med. 2000;4:199-204. 